\title{
Persistence of goitre in children post-salt iodization in Islamic Republic of Iran: autoimmune status
}

M.H. Dabbaghmanesh, ${ }^{1}$ A. Sadegholvaad, ${ }^{1}$ F. Ejtehadi ${ }^{1}$ and G. R.Omrani ${ }^{1}$

$$
\begin{aligned}
& \text { استمرار الدُراق (ضخامة الدرقية) بين الأطفال بعد معالجتهم بأملاح اليود في جمهورية إيران الإسلامية: حالة } \\
& \text { التمنيع للذات } \\
& \text { محمد حسين دباغ منش، عبد الصمد صادق الوعد، فرداد اجتهادي، علام حسين رنجبر عمراني }
\end{aligned}
$$

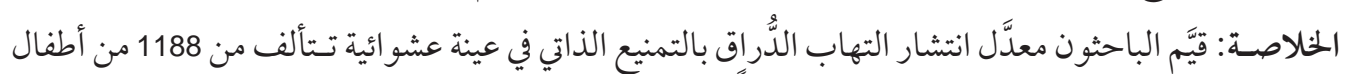

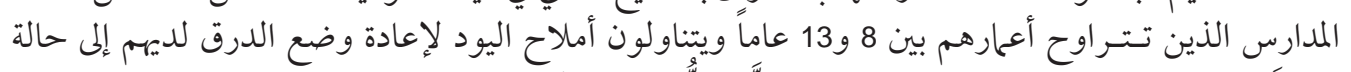

ABSTRACT We evaluated the prevalence of autoimmune thyroiditis in a random sample of 1188 schoolchildren aged 8-13 years with normalized iodine intake in the Islamic Republic of Iran. The prevalence of goitre was $39.6 \%$; the majority had palpable but non-visible goitre. Of a subsample of 500 children, median urinary iodine excretion $(18 / 8 \mu \mathrm{g} / \mathrm{dL})$ indicated normal iodine intake. Thyroid peroxidase (TPO) antibody was positive in $3.7 \%$ of children and was significantly correlated with the prevalence of goitre and hypothyroidism. No correlation was seen between urinary iodine excretion and positive TPO antibody, mean TPO antibody, hypothyroidism or prevalence of goitre. Autoimmune thyroiditis explains some cases of goitre but other goitrogenic factors need to be evaluated.

\begin{abstract}
Persistance du goitre chez les enfants après iodation du sel en République islamique d'Iran : état auto-immun

RÉSUMÉ Nous avons évalué la prévalence de la thyroïdite auto-immune dans un échantillon aléatoire de 1188 élèves âgés de 8 à 13 ans recevant un apport d'iode standard en République islamique d'Iran. La prévalence du goitre était de $39,6 \%$; dans la majorité des cas, ce goitre était palpable mais non visible. Dans un sous-échantillon de 500 enfants, la valeur moyenne d'excrétion urinaire d'iode $(18 / 8 \mu \mathrm{g} / \mathrm{dL})$ indiquait un apport d'iode normal. Les anticorps anti-thyroperoxydase (TPO) étaient positifs chez $3,7 \%$ des enfants et significativement corrélés avec la prévalence du goitre et de l'hypothyroïdie. Aucune corrélation n'a été observée entre l'excrétion urinaire de l'iode et les anticorps anti-TPO positifs, les taux moyens d'anticorps anti-TPO, l'hypothyroïdie ou la prévalence du goitre. La thyroïdite auto-immune explique certains cas de goitre mais les autres facteurs goitrigènes doivent être évalués.
\end{abstract} ${ }^{1}$ Department of Internal Medicine, Endocrine and Metabolism Research Centre, Shiraz University of Medical
Sciences, Shiraz, Islamic Republic of Iran (Correspondence to M.H. Dabbaghmanesh: dabbaghm@sums.ac.ir). Received: 10/07/06; accepted: 27/11/06 


\section{Introduction}

Iodine deficiency has a number of important health consequences which together are called iodine deficiency disorder. The most serious of these are endemic goitre, hypothyroidism, stillbirth, congenital abnormalities and impairment of intellectual development [1].

Previous national surveys of iodine deficiency in the Islamic Republic of Iran revealed endemic goitre and iodine deficiency in all provinces [2]. The main strategy for control of iodine deficiency was countrywide salt iodization and mandatory production of iodized salt for household use, which started in 1994. Subsequently, the Islamic Republic of Iran became iodine sufficient and this achievement was recognized by the World Health Organization (WHO) Regional Office for the Eastern Mediterranean (EMRO) in the year 2000 [3].

Despite this success, goitre is still endemic in schoolchildren [4]. Now that iodine intake is normalized, causes other than iodine deficiency have to be considered in schoolchildren with thyroid enlargement. The most important differential diagnosis for persistence of goitre is thyroid autoimmunity.

A study in which iodide was administered to patients with goitre showed evidence of autoimmunity [5], with $42.8 \%$ developing positive thyroid autoantibodies. Another study showed that increased iodine intake was associated with an increased incidence of autoimmune thyroiditis [6]. However, no study has evaluated the contribution of autoimmunity to the prevalence of goitre in Iranian schoolchildren after the salt iodization programme. We therefore aimed to assess thyroid function and the prevalence of positive thyroid autoantibodies in Iranian schoolchildren 10 years after iodine supplementation was started.

\section{Methods}

The study was conducted in Marvdasht, an urban community of approximately 150000 inhabitants, situated $50 \mathrm{~km}$ from Shiraz, the capital of Fars province, from April to November 2005.

The sample was selected from all children aged 8-13 years attending the 97 schools in the area. The sampling frame consisted of the list of schools. We selected 40 clusters from this list by cluster random sampling and 100 schoolchildren in each of the 6 year groups were chosen randomly from the clusters. The selected children (600 boys, 600 girls) and their parents were invited to participate in the study; all except 12 accepted. These 1188 children (598 boys, 590 girls) were enrolled after their parents provided written informed consent. None of them was taking thyroid medication.

For each child, the size of the thyroid was determine by an endocrinologist and graded as non-palpable goitre (grade 0), palpable but non-visible goitre (grade 1) or palpable and visible goitre (grade 2), according to the joint criteria of WHO, United Nations Children's Fund (UNICEF) and the International Council for Control of Iodine Deficiency Disorders (ICCIDD) [7].

Simple random sampling was used to recruit a subsample of 500 ( 252 boys and 248 girls) from the 1188 children to measure levels of urinary iodine excretion (UIE) and serum level of free thyroxine $\left(\mathrm{T}_{4}\right)$, free triiodothyronine $\left(\mathrm{T}_{3}\right)$, thyroid-stimulating hormone (TSH) and thyroid peroxidase (TPO) antibodies. All the children accepted. Blood samples were obtained in the early morning and the serum was separated within 1 hour of sampling by centrifugation

For measurement of UIE levels, urine samples were obtained in the morning and were frozen until analysis by the digestion method. According to WHO/ICCIDD

المجلة الصحية لشرق المتوسط، منظمة الصحة العالمية، المجلد الخامس عشر، العدد ب، 9 ب. 
recommendations, the median UIE for a population should be $10 \mu \mathrm{g} / \mathrm{dL}$. Mild iodine deficiency is UIE $5.0-9.9 \mu \mathrm{g} / \mathrm{dL}$, moderate deficiency $2.0-4.9 \mu \mathrm{g} / \mathrm{dL}$ and severe deficiency $<2.0 \mu \mathrm{g} / \mathrm{dL}[7]$. Not more than $20 \%$ of samples from a population should have $\mathrm{UIE}<5.0 \mu \mathrm{g} / \mathrm{dL}[8]$.

Free $\mathrm{T}_{4}$ and $\mathrm{T}_{3}$ measurements were carried out on serum by radioimmunoassay (RIA-gnost T3 and T4, CIS Bio International, France) and TSH was assayed by an immunoradiometric technique (Biosource Europe, Belgium). The normal ranges for free $\mathrm{T}_{4}$, free $\mathrm{T}_{3}$ and TSH were defined as $7-18 \mathrm{pg} / \mathrm{mL}, 2.00-4.25 \mathrm{pg} / \mathrm{mL}$ and 0.3-3.9 IU/mL respectively. Radioimmunoassay was also used for detection of TPO antibodies (TPO antibody kit, Radim, Italy); titres $\geq 50 \mu \mathrm{g} / \mathrm{dL}$ were considered positive.
For statistical analysis, we used SPSS, version 11.5 . Data which were normally distributed were expressed as mean and standard deviation (SD) and were compared by $t$-test. Parameters not normally distributed were expressed as median and were compared by Mann-Whitney and KruskalWallis tests. Comparisons between frequencies were made by the chi-squared test. Statistical significance was set at $P<0.05$.

\section{Results}

\section{Prevalence of goitre}

Thyroid enlargement of grade 1 was seen in $37.0 \%$ and grade 2 in $2.6 \%$ of the whole group of students. Among girls $40.1 \%$ had goitre (37.6\% grade $1,2.5 \%$ grade 2 ), whereas in boys $39.0 \%$ had goitre $(36.3 \%$ grade 1 ,

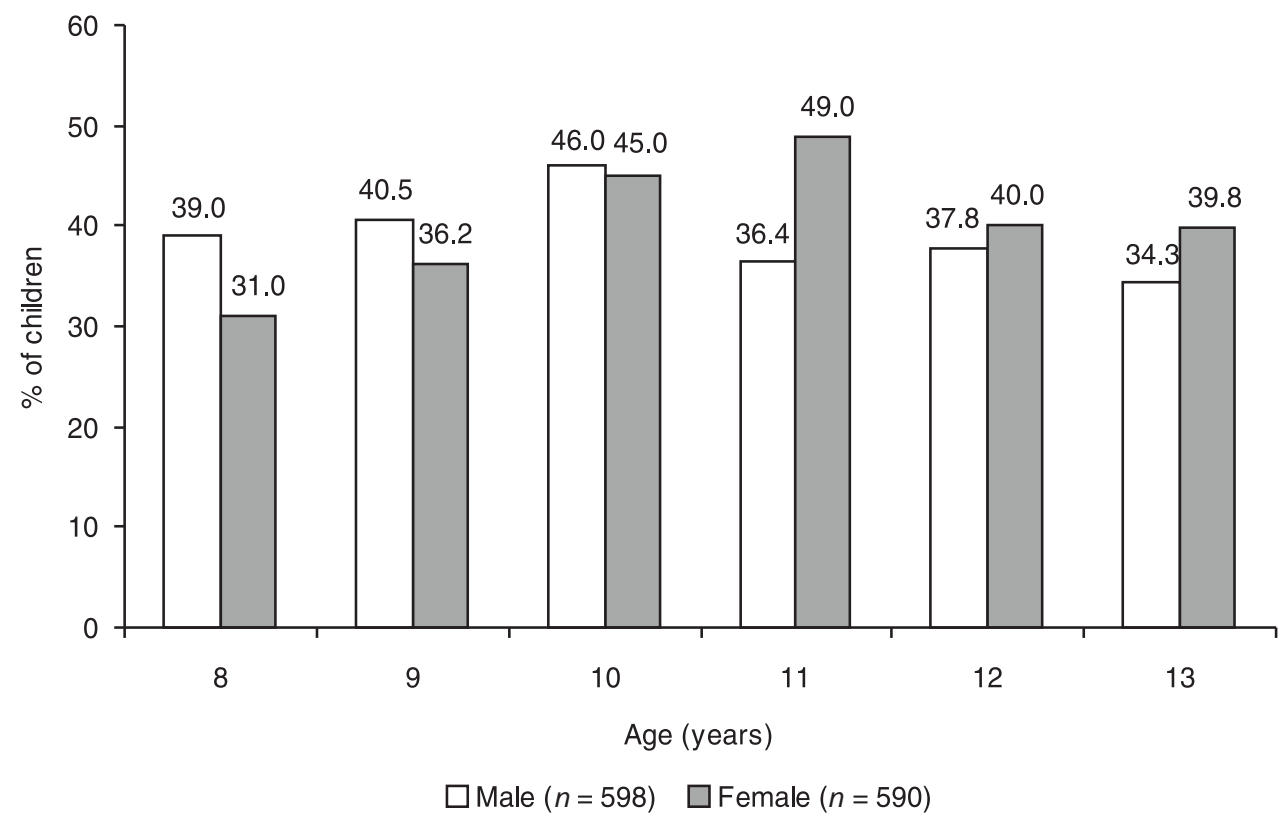

Figure 1 Prevalence of goitre (grade 1 or 2 ) in male and female schoolchildren in Marvdasht ( $n$ = 1188)

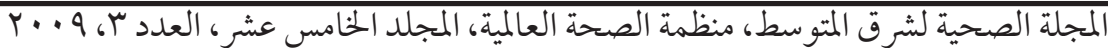


$2.7 \%$ grade 2). No significant difference was observed in goitre prevalence between the age groups and sexes (Figure 1).

\section{UIE}

The median UIE of the subsample was $18.8 \mu \mathrm{g} / \mathrm{dL}$, with no significant difference between boys and girls $(17 \mu \mathrm{g} / \mathrm{dL}$ versus $22.4 \mu \mathrm{g} / \mathrm{dL}$ respectively); $12.2 \%$ of children had UIE $<5 \mu \mathrm{g} / \mathrm{dL}$. UIE was not related to age or sex. The median UIE in students who had goitre was $20 \mu \mathrm{g} / \mathrm{dL}$ and in those without goitre was $18 \mu \mathrm{g} / \mathrm{dL}$, but the difference was not statistically significant (Figure 2).

\section{$T S H, T_{4}, T_{3}$}

The mean TSH concentration of the subsample was 2.5 (SD 3.1) IU/mL and mean $\mathrm{T}_{4}$ and $\mathrm{T}_{3}$ concentrations were 13.1 (SD 2.9) $\mathrm{pg} / \mathrm{mL}$ and $3.8 \mathrm{pg} / \mathrm{mL}$ (SD 1.0) respective- ly, without age- or sex-related differences. In $2.5 \%$ of the children, TSH values were $>3.9 \mathrm{IU} / \mathrm{mL}$. A concentration $>10 \mathrm{IU} / \mathrm{mL}$ was found in only $0.8 \%$ of the children. The prevalence of hyperthyroidism was $0.2 \%$.

\section{TPO antibodies}

Positive TPO antibodies were found in 3.7\% of the schoolchildren $(7.6 \%$ in girls versus $0.5 \%$ in boys). The mean TPO antibody titres were 26.9 (SD 191) IU/mL and 46 (SD 257) $\mathrm{IU} / \mathrm{mL}$ in boys and girls respectively $(P<0.001)$.

Of the children with goitre, $5.1 \%$ had positive TPO antibody, with mean 38.9 (SD 2.3) $\mathrm{IU} / \mathrm{mL}$, whereas in children without goitre, the prevalence of positive TPO antibody was $2.7 \%$, with mean 18.8 (SD 183) $\mathrm{IU} / \mathrm{mL}(P<0.001)$.

Positive TPO antibody was found in $6.7 \%$ of schoolchildren with hypothyroid-

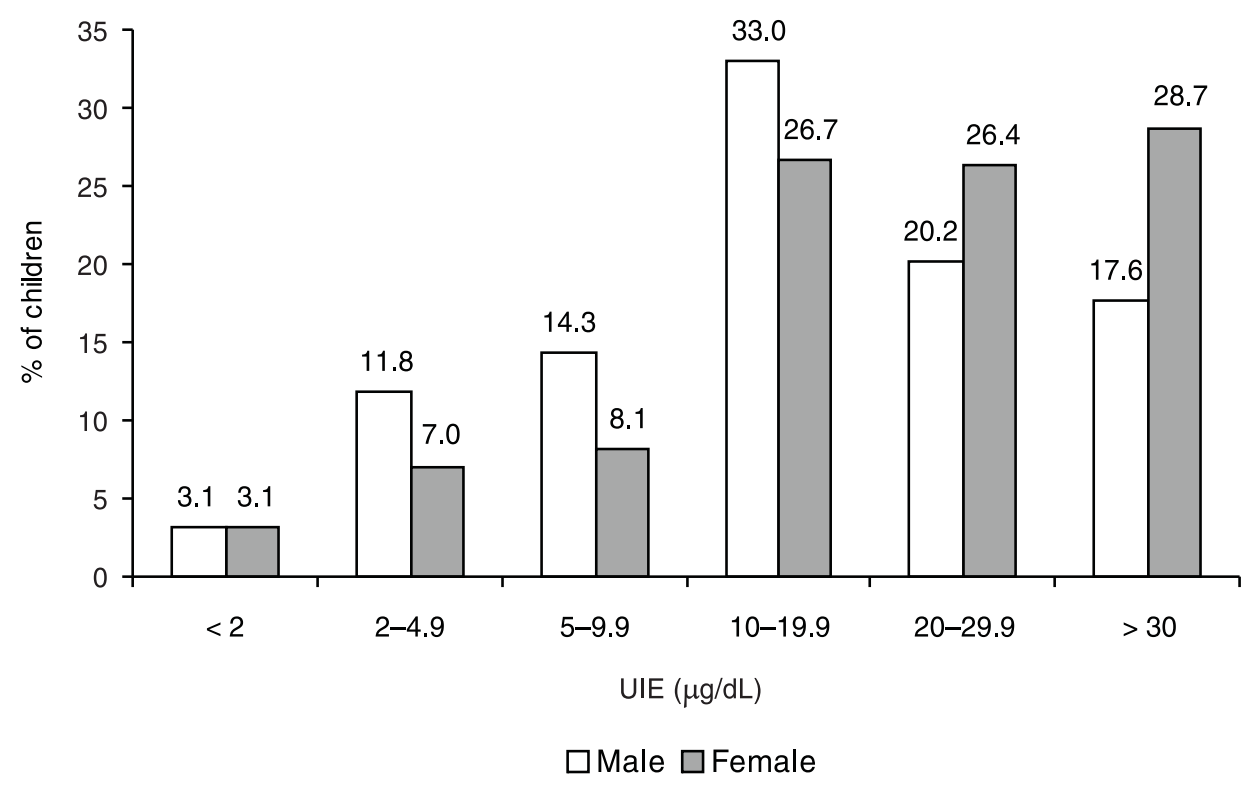

Figure 2 Distribution of urinary iodine excretion (UIE) level in male and female schoolchildren in Marvdasht $(n=500)$

المجلة الصحية لشرق المتو سط، منظمة الصحة العالمية، المجلد الخامس عشر، العدد ب، 9 +. 
ism but in euthyroid children the positive rate was $3.4 \%(P<0.001)$. There was no significant difference between the presence of thyroid dysfunction and TPO antibody status with level of UIE.

\section{Discussion}

There has been remarkable global success in the control of iodine deficiency disorders via iodization of salt $[9,10]$. Although several national surveys in the Islamic Republic of Iran showed a significant reduction in the prevalence of goitre, it is still endemic, even though the country is no longer considered iodine deficient. Despite this progress, our findings indicate persistence of endemic goitre in $39.6 \%$ of schoolchildren more than 10 years after salt iodization began. The same problem has been reported by others, suggesting that there may be goitrogenic factors other than iodine deficiency [11-14]. The most common cause of goitre in juvenile populations with normal iodine intake is autoimmune thyroiditis [15]. Genetic factors [16] as well as environmental factors have been shown to induce thyroid autoimmunity [17-19]. Excess iodine induces thyroiditis in genetically susceptible animals $[20,21]$. The mechanism may be that excess dietary iodine triggers thyroid autoimmunity by increasing the immunogenicity of thyroglobulin [22] or by production of free radicals $[20,23]$. After the introduction of iodine, an increase in lymphocytic infiltration in thyroidectomy specimens and in prevalence of positive antithyroid antibodies have been seen $[5,6,24]$.

However, iodization has not always resulted in the development of autoimmune thyroid disease [25,26]. In Indian girls there was no definite correlation between UIE level and thyroid autoimmunity [27]. Ad- ministration of iodized salt to children in Morocco did not result in any thyroid autoimmunity [28]. We did not find a relationship with the presence or absence of thyroid dysfunction or with thyroid autoantibody status and UIE. It seems that the response of the immune system to iodine intake is heterogeneous, depending on the immunogenic background of individuals. In this study, the prevalence of positive anti-TPO antibody, hypothyroidism and hyperthyroidism were compatible with data reported from an iodine-sufficient area [29].

We should mention that there may be inter- and intra-observer variation with the palpation method, especially in the assessment of smaller sizes of goitre. Determination of thyroid size by ultrasonography is the preferred method but we used palpation because ultrasonography of these numbers of schoolchildren is cumbersome and because, in the absence of ultrasonography, the palpation method is regarded as a simple and acceptable alternative.

To sum up, autoimmunity of the thyroid might explain to some extent the prevalence of goitre in the post-iodization phase in this area of the Islamic Republic of Iran, but it is necessary to consider other goitrogens. High thiocyanide exposure can account for a proportion of residual goitre after salt iodization programmes in some areas [30]; deficiency of iron and iodine are major overlapping health concerns in developing countries, and iron deficiency impairs thyroid metabolism and may limit the effectiveness of iodine intervention programmes [31]; vitamin A may modify thyroid hormone metabolism [32]; and selenium is an integral component of enzyme glutathione peroxidase and is a known contributor to endemic goitre [33]. We suggest further investigations into the role of these factors in the persistence of goitre in this area. 


\section{References}

1. Hetzel BS. The prevention and control of iodine deficiency disorders. Amsterdam, Elsevier, 1993:1-16 (Administrative Committee on Coordination/Subcommittee on Nutrition State of the Art Series Nutrition Policy Discussion Paper No. 3).

2. Azizi F, Navai L, Fattahi F. Goiter prevalence, urinary iodine excretion, thyroid function and anti-thyroid antibodies after 12 years of salt iodization in Shahriar, Iran. International journal for vitamin and nutrition research, 2002, 72(5): 291-5.

3. Azizi F, Mehran L. Experiences in the prevention, control and elimination of iodine deficiency disorders: a regional perspective. Eastern Mediterranean health journal, 2004, 10(6):761-70.

4. Azizi F et al. Sustainable control of iodine deficiency in Iran: beneficial results of the implementation of the mandatory law on salt iodization. Journal of endocrinological investigation, 2002, 25(5):409-13.

5. Boukis MA et al. Thyroid hormone and immunological studies in endemic goiter. Journal of clinical endocrinology and metabolism, 1983, 57:859-62.

6. Harach HR et al. Thyroid carcinoma and thyroiditis in an endemic goitre region before and after iodine prophylaxis. Acta endocrinologica, 1985, 108:55-60.

7. World Health Organization, United Nations Children's Fund, and International Council for Control of lodine Deficiency Disorders. Indicators for assessing iodine deficiency disorders and their control through salt iodization. Geneva, World Health Organization, 1994 (WHO/NUT 94.6).

8. International Council for Control of lodine Deficiency Disorders. Indicators for assessing IDD status. IDD newsletter, 1999, 15:33-8 (http://www.iccidd.org/media/
IDD\%20Newsletter/1991-2006/aug1999. htm, accessed 22 January 2009).

9. Assessment of iodine deficiency disorders and monitoring their elimination. Geneva, World Health Organization, 2001 (WHO/ $\mathrm{NHD} / 01.1$.

10. Hetzel BS. Eliminating iodine deficiency disorders-the role of the International Council in the global partnership. Bulletin of the World Health Organization, 2002, 80:410-3.

11. Untoro J, Ruz M, Gross R. Low environmental selenium availability as an additional determinant for goiter in East Java, Indonesia. Biological trace element research, 1999, 70:127-36.

12. Doufas $A G$ et al. The predominant from of nontoxic goiter in Greece is now autoimmune thyroiditis. European journal of endocrinology, 1999, 140:505-11.

13. Enguix A et al. Efectividad de la yodoprofilaxis en la prevención del bocio endémico en el área suroccidental de Asturias [The efficacy of iodine prophylaxis in the prevention of endemic goiter in the southwestern area of Asturias]. Anales de medicina interna, 1995, 12:182-6.

14. Filteau SM et al. lodine deficiency alone can not account for goiter prevalence among pregnant women in Modhupur, Bangladesh. European journal of clinical nutrition, 1994, 48:293-302.

15. Braverman LE. lodine induced thyroid disease. Aacta medica austriaca, 1990, 17 (Suppl.):129-33.

16. Schleusener $\mathrm{H}$ et al. The relevance of genetic susceptibility in Graves disease and immune thyroiditis. Experimental and clinical endocrinology, 1991, 97:127-32.

17. Glaser R, Kiecolt-Glaser JK. Handbook of human stress and immunity. London, Academic Press, 1994:1-414. 
18. Holt PG. Immune and inflammatory function in cigarette smokers. Thorax, 1987, 42:241-9.

19. Premawardhana LD al. Increased prevalence of thyroglobulin antibodies in Sri Lankan schoolgirls-is iodine the cause? European journal of endocrinology, 2000, 143:185-8.

20. Sundick RS, Bagchi N, Brown TR. The role of iodine in thyroid autoimmunity from chickens to humans: a review. Autoimmunity, 1992, 13:61-8.

21. Brown TR, Bagchi N. The role of iodine in the development of autoimmune thyroiditis. International reviews of immunology, 1992, 9:167-82.

22. Sundick RS et al. The incorporation of dietary iodine into thyroglobulin increases its immunogenicity. Endocrinology, 1987, 120:2078-84.

23. Vitale $M$ et al. lodide excess induces apoptosis in thyroid cells through a P53-independent mechanism involving oxidative stress. Endocrinology, 2000, 141:598-605.

24. Oechslin E, Hedinger C. Thyreoiditis lymphomatosa Hashimoto und endemische Struma [Hashimoto's lymphomatous thyroiditis and endemic struma]. Schweizerische medizinische Wochenschrift, 1985, 115:1182-91.

25. Knobel M, Medeiros-Neto G. lodized oil treatment for endemic goiter does not induce the surge of positive serum concentrations of anti-thyroglobulin or anti-microsomal autoantibodies. Journal of endocrinological investigation, 1986, 9:321-4.
26. Lazarus $\mathrm{JH}$ et al. Endemic goiter in Senegal: thyroid function, etiological factors and treatment with oral iodized oil. Acta endocrinologica, 1992, 126:149-54.

27. Marwaha PK et al. Hashimoto's thyroiditis: countrywide screening of goitrous healthy young girls in postiodization phase in India. Journal of clinical endocrinology and metabolism, 2000, 58:3798-802.

28. Zimmermann MB et al. Introduction of iodized salt to severely iodine deficient children does not provoke thyroid autoimmunity: a one-year prospective trial in northern Morocco. Thyroid, 2003, 13:199-203.

29. Garcia-Mayor RV et al. Effect of iodine supplementation on a pediatric population with mild iodine deficiency. Thyroid, 1999, 9:1089-93.

30. Marwaha RK et al. Residual goiter in the postiodization phase: iodine status, thiocyanate exposure and autoimmunity. Clinical endocrinology, 2003, 59:672-81.

31. Zimmermann M et al. Persistence of goiter despite oral iodine supplementation in goitrous children with iron deficiency anemia in Cote d'Ivoire. American journal of clinical nutrition, 2000, 71:88-93.

32. Wolde-Gebriel $Z$ et al. Interrelationship between vitamin $\mathrm{A}$, iodine and iron status in schoolchildren in Shoa Region, Central Ethiopia. British journal of nutrition, 1993, 70:593-607.

33. Vanderpas JB et al. lodine and selenium deficiency associated with cretinism in northern Zaire. American journal of clinical nutrition, 1990, 52:1087-93. 